\title{
Evaluación comparativa de dos métodos de recuperación espermática de epidídimos bovinos post-mortem
}

\author{
Comparative evaluation of two methods of spermatic recovery of post-mortem bovine \\ epididymis
}

\section{Benítez-González Edgar ${ }^{1}$ e.benitez27@hotmail.com, Chamba-Ochoa Hermógenes ${ }^{1 \star}$ hermogenes.chamba@unl.edu.ec, Sánchez-Sánchez Efrén ${ }^{1}$ efrensanchez20@yahoo.es, Luzón-Cevallos Félix ${ }^{1}$ felixluzon9_1990@hotmail.com, Sánchez-Carrillo Jairo² jarengasanz@gmail.com}

\begin{abstract}
${ }^{1}$ Universidad Nacional de Loja - Carrera de Medicina Veterinaria y Zootecnia. Ecuador. ${ }^{2}$ Ministerio de Agricultura, Ganadería, Acuacultura y Pesca, Agencia Gualaquiza. Ecuador. *Author responsible and correspondence: Universidad Nacional de Loja - Carrera de Medicina Veterinaria y Zootecnia., Ciudad Universitaria "Guillermo Falconí Espinosa", Av. Pío Jaramillo Alvarado s/n. e-mail: hermogenes.chamba@unl.edu.ec
\end{abstract}

\section{RESUMEN}

Determinar el método adecuado para recuperar espermatozoides epididimarios en bovinos en diferentes tiempos de recuperación post-mortem fue el objetivo del presente estudio. Testículos de 50 toros de diferentes razas y edades, en buen estado sanitario, fueron obtenidos luego del sacrificio en la plaza de rastro de Loja, Ecuador; evaluándose dos métodos de recolección seminal: lavado retrógrado y slicing. Los testículos/epidídimos fueron transportados en solución de cloruro de sodio al $0.9 \%$ y almacenados durante $2,4,8,12$ y 24 horas, a $5^{\circ} \mathrm{C}$, evaluando calidad espermática en relación al tiempo transcurrido desde su sacrificio, hasta la obtención espermática en el laboratorio. Los parámetros evaluados fueron: volumen, concentración, vitalidad, motilidad masal, motilidad individual, y espermatozoides normales. En el análisis de resultados se utilizó estadística descriptiva y para el análisis de varianza se utilizó el test de Tukey para determinar diferencias estadísticas entre promedios. Los espermatozoides epididimarios mostraron: motilidad masal $60,4 \% \pm 4,75$; motilidad individual $50,7 \% \pm 4,75$; vitalidad $60,6 \% \pm 3,85$; anormalidades $8,78 \% \pm 1,4$; no hubo diferencia significativa ( $p>0.05$ ) entre protocolos, recogiendo volúmenes promedios de $2,2 \pm 05 \mathrm{ml}$, y concentración de $63,08 \% \pm 2,05$, el porcentaje de espermatozoides vivos fue mayor utilizando el método de lavado retrógrado $62,08 \pm 4,2$. Concluyéndose que es posible recolectar espermatozoides vivos de la cola del epidídimo de toros postmortem siendo su vitalidad directamente proporcional al tiempo de almacenamiento.

Palabras clave: Epididimario, calidad espermática, lavado retrógrado, slicing.

\section{ABSTRACT}

Determining the appropriate method to recover epididymal spermatozoa in bovines at different post-mortem recovery times was the objective of the present study. Testicles of 50 bulls of different breeds and ages, in good sanitary condition, were obtained after the slaughter in the animal commercialization square of Loja, Ecuador; evaluating two methods of seminal collection: retrograde flushing and slicing. The testes/epididymis were transported in $0.9 \%$ sodium chloride solution and stored for 2, 4, 8, 12 and 24 hours at $5{ }^{\circ} \mathrm{C}$, evaluating sperm quality in relation to the time elapsed from slaughter to sperm production in the laboratory. The evaluated parameters were: mass motility, individual motility, percentage of viable sperm, and normal. In the analysis of the results descriptive statistics were used and for the variance analysis Tukey test were used to determine the statistical differences between averages. The epididymal spermatozoa showed: mass motility $60.4 \% \pm 4.75$; individual motility $50.7 \% \pm 4.75$; vitality $60.6 \% \pm 3.85$; abnormalities $8.78 \% \pm 1.4$; there is no significant difference $(p>0.05)$ between protocols, getting average volumes of $2.2 \pm 05 \mathrm{ml}$, concentration of $63.08 \% \pm 2.05$, the percentage of living sperm was more when the method of retrograde wash was used. It is concluded that is possible collect living sperm from the post-mortem epididymis bull's tail, being its vitality directly proportional to the storage time.

Key words: Epididymal, spermatic quality, retrograde washing, slicing. 


\section{INTRODUCTION}

The collection of bovine semen through the use of conventional methods such as artificial vagina and electroejaculation has allowed the establishment of germplasm banks from selected breeding males; however, when a bull or other animal dies unexpectedly, its genetic material is lost. However, recovering sperm from a recently killed or slaughtered male implies that there is an interest in using their gametes for the purpose of get offspring at some point. One way to preserve the germplasm of these animals is to collect sperm from the epididymis (Martins et al., 2009). This post-mortem procedure is considered an important tool in the use of spermatozoa of animals in danger of extinction.

Spermatozoa collected from the epididymis can be cryopreserved or used immediately in vitro fertilization (Martins et al., 2007) or intracytoplasmic injection into oocytes (James et al., 2002); this circumstance may occur in unpredictable events such as accidents, poisonings or diseases that can suddenly trigger orchiectomy, death or euthanasia of bulls of genetic or sentimental value (Armas et al., 2011). In these cases, owners should not only confront the loss of the animal, but also the loss of desirable genetic material.

In this sense, it is possible to obtain spermatozoa until a certain time after the animal death, which are recovered from the tail of the epididymis with motility and fertilizing capacity (Yu and Leibo, 2002); this is mainly due to the fact that two major events occur in the epididymis: maturation and sperm storage. The maturation or progressive development of the fertilizing capacity of the spermatozoa occurs in the head and the body of the epididymis and the storage occurs in the tail of the same. Thus, the production of potentially fertilizing epididymal spermatozoa that are stored in the tail of the epididymis may be the only option to preserve the genetic material of a male of high genetic value, after his death or medical orchiectomy (Tittarelli et al., 2007).

The main site of sperm storage in the male reproductive tract is the tail of the epididymis. This part has a relatively broad light in which high concentrations of sperm are stored. A functional disorder of the epididymis can lead to an abnormal composition of the epididymis plasma, decreased motility of abnormal spermatozoa and clinical spermatozoa (Oyeyemi and Ubiogoro, 2005).

It is important to establish a method for collecting spermatozoa from breeding stallions that have died from natural causes or accidents, so that offspring can be obtained from these bulls. Thus, the spermatozoa collected from the tail of the epididymis could be implemented to propagate the genetic quality of post-mortem bulls, since the spermatozoa found there have a fertilizing capacity (Soler et al., 2005). 
Due to the aforementioned and taking into account the importance of the spermatozoa recovery that would be lost by the death of the animals, the objective of the present work is based on the spermatozoa obtained from the epididymis tail of post-mortem bulls to evaluate their viability; as well as to evaluate the protocols of retrograde flushing and slicing of the epididymis to obtain semen; evaluating the sperm viability according to protocols of collection from the obtaining of the testicles in the animal commercialization square, until obtaining the spermatozoa in the laboratory; assessing the period of conservation in refrigeration in order to determine the protocol or more efficient collection method of epididymal spermatozoa.

\section{MATERIAL AND METHODS}

\section{Place of study and animals}

For the present study, a total of 50 pairs of bull testicles diagnosed healthy on the antemortem examination, of different racial types and ages, were used in the Municipal slaughterhouse of Loja canton, while the processing of the samples was carried out in the Laboratory of Animal Reproduction, located in Punzara Experimental Farm of the National University of Loja, Ecuador.

\section{Collection and transport of samples}

The testicles were collected from 50 bulls of different races and aged between two and four years, during 10 visits to Municipal slaughterhouse of Loja. The steps followed for the collection of the testicles were: collection of scrotal sacs with their testicles included; each scrotal sac was identified with the number corresponding to the order in which they were collected, in addition to the date and time of collection; each scrotal sac was wiped with paper towels, the testes/epididymis were ligated into the spermatic cord; each was placed in sealed and identified plastic bags and then transported from the collection site to the laboratory within a maximum of 30 minutes at an initial temperature of $35^{\circ} \mathrm{C}$. To achieve this temperature was used thermal bags with tempered water at $37^{\circ} \mathrm{C}$.

Once in the laboratory, each testicle was placed in a Petri dish, where an external wash of the epididymis tail was performed with physiological saline solution. To remove blood and external contaminants, the connective tissue that covers the tail was removed by careful dissection, avoiding the rupture of the blood vessels and the epididymal duct; the testes were then separated from the epididymides and washed with saline; a dissection of the epididymis tail was performed, removing the tunica albuginea, thus leaving a free portion of the vas deferens. Then the secretion of the same was obtained according to each method of collection studied, ie: collection of retrograde flow and slicing of the epididymis (Slicing), proceeding as follows: 


\section{First method (retrograde flow collection)}

The epididymis, already separated from the testis, was placed in a Petri dish, with ringer lactate preheated at $37^{\circ} \mathrm{C}$, for the purpose of washing blood residues; then the nearest portion of the mid-tail of the epididymis was located to make a cross-section with the scalpel, before the diameter of the epididymis was reduced. In order to obtain as much spermatozoa as possible, a needle (20 gauge, 21,22 , or 23 , according to the internal diameter of each vas deferens) was placed into the lumen of the free portion of the vas deferens. A syringe was fitted with $10-15 \mathrm{ml}$ of "PBS washing medium" at $37^{\circ} \mathrm{C}$ with a clamp being placed against the needle on the walls of the vas deferens, thereby preventing the loss of the wash liquid by reflux. The fluid obtained with epididymal spermatozoa was centrifuged at $(300 \mathrm{~g} / 5 \mathrm{~min})$ to concentrate the sample. The supernatant obtained was removed and discarded, at a concentration of $1: 1$ at $37^{\circ} \mathrm{C}$.

\section{Second method (slicing of the epididymis)}

The epididymis was aseptically separated from the testis, placed in a Petri dish with lactated ringer at $37^{\circ} \mathrm{C}$, to wash away blood residues. Spermatozoa were recovered by the slicing method, with a surgical scissors in a Petri dish, containing $15 \mathrm{ml}$ of PBS medium at $37^{\circ} \mathrm{C}$; this content was sucked into a $20 \mathrm{ml}$ syringe. To be purified through a sterile filter; it was transferred to falcon tubes $(15 \mathrm{ml})$, and then centrifuged at a rate of (300 $\mathrm{g} / 5 \mathrm{~min})$. The obtained supernatant was removed and discarded; and a pre-dilution with AndroMed in a ratio of $1: 1$ at $37^{\circ} \mathrm{C}$ was performed.

\section{Preparation of the diluent}

$2 \mathrm{ml}$ of AndroMed was poured into a graduated falcon tube, $8 \mathrm{ml}$ of doubly distilled water, tempered at $37^{\circ} \mathrm{C}$, was added to the concentrate and mixed with the aid of the vortex (mechanical stirrer) until the dilution was homogenized. This dilution was performed for each sample individually, the same one that should be prepared in a water bath between 35 and $37^{\circ} \mathrm{C}$; then the pre-dilution of the semen was performed in a 1: 1 ratio; for this the diluent should have the same temperature as the sperm. After the semen evaluation, the final dilution was immediately carried out, which consisted of $2 \mathrm{ml}$ of prediluted semen plus $8 \mathrm{ml}$ of the prepared diluent. This final dilution must progressively decrease temperature until the laboratory temperature $\left(18\right.$ to $\left.22^{\circ} \mathrm{C}\right)$ is reached. Subsequently the temperature is lowered with cooled water $\left(8-10^{\circ} \mathrm{C}\right)$, the temperature must be equilibrated for at least 1 hour, then cooled to $5^{\circ} \mathrm{C}$. 


\section{Microscopic evaluation of the seminal samples}

To perform the microscopic evaluation it was necessary to wait between 40 and 45 minutes in order to observe the movements of the epididymal spermatozoa, during which time the seminal samples and the material used in a water bath at $37^{\circ} \mathrm{C}$ were maintained; after this time it was possible to estimate the percentages of motile and progressive movements of the sperm cells; $5 \%$ eosin and $10 \%$ nigrosin were used for the staining and smearing of the samples; the microscopic evaluation was done with a 40X and 100X lens. The following characteristics were analyzed: volume, concentration, morphology, vitality, mass motility and individual motility.

a) - Mass motility: a drop of semen of 10 to $20 \mu \mathrm{l}$ was placed, on an object holder tempered at $37^{\circ} \mathrm{C}$, without placing the covers objects; it is observed with the $10 \mathrm{X}$ and $40 X$ lens in a biological binocular microscope XSP63, the percentage of mass motility. It was graded according to the evaluative criteria proposed in table 1.

Table 1. Percentage of mass motility and evaluative criteria

\begin{tabular}{clcc}
\hline $\begin{array}{c}\text { DESCRITIVE } \\
\text { VALUE }\end{array}$ & \multicolumn{1}{c}{ ASPECT OF THE MODEL } & $\begin{array}{c}\text { \% MOTILE } \\
\text { CELLS }\end{array}$ & $\begin{array}{c}\text { EVALUATIVE } \\
\text { CRITERIA }\end{array}$ \\
\hline Very good & Movement in vigorous waves and rapid eddies & $80-90 \%$ & ++++ \\
Good & Eddies and slower waves & $60-80 \%$ & +++ \\
Regular & No eddies, but with generalized oscillations & $40-60 \%$ & ++ \\
Bad & Poor or no motility & $0-40 \%$ & $+0-$ \\
\hline & Adapted of; Derivaux (1976), Hafez (1989) and Baracaldo (2007) &
\end{tabular}

b)- Individual Motility: 10 $\mu$ l of semen was placed in an object holder and covered with covered objects, both tempered at $37^{\circ} \mathrm{C}$, observed with the $40 \mathrm{X}$ lens, spermatozoa were evaluated with progressive rectilinear movement through the observed field; both in the mass motility and for the individual one. For the evaluation the thermal template is placed in the microscope so as to maintain the temperature. To determine the percentage of individual motility was scored according to the values proposed in table 2 (Chamba Ochoa, 2017).

Table 2. Scale based on the percentage of motile cells.

\begin{tabular}{ll}
\hline Descriptive valious & \multicolumn{1}{c}{$\%$ motile cells } \\
\hline Very good & $80-100 \%$ of motile cells \\
Good & $60-79 \%$ of motile cells \\
Regular & $40-59 \%$ of motile cells \\
Bad & Less than $40 \%$ of motile cells \\
Aapted of Salisbury (1978), Hafez (1989) and Barth (2000).
\end{tabular}


c)- Sperm concentration: to determine sperm concentration, a 1: 200 dilution was performed, ie $10 \mu \mathrm{l}$ of pure semen was mixed in $2 \mathrm{ml}$ of formalin saline solution; $(0.9 \%$ sodium chloride, $0.1 \%$ formaldehyde in distilled water) and then the solution was homogenized (Chamba Ochoa, 2017). With the help of the vortex the sample was homogenized, after which $10 \mu \mathrm{l}$ of the dilution was placed in the Neubauer chamber; and then took the camera under the microscope where it was observed with the $40 \mathrm{X}$ lens.

For counting, the sperm heads observed in 5 tables were counted from the large central table and the following formula was applied.

$$
\text { CE } \mathrm{ml}=\mathrm{n} \times 200 \times 10 \times 5 \times 1000
$$

where:

$\mathrm{n}=$ Number of cells counted

200 = Dilution Factor

$10=$ Camera height of 0.1

$5=$ number of squares counted

$1000=$ Conversion to $\mathrm{cm}^{3}$

The result obtained from the sperm concentration was in millions $/ \mathrm{ml}$

d) - Morphology: to perform the morphological evaluation, a total of 100 sperm per sample was evaluated, in order to determine the percentage of abnormalities. Vital staining of $5 \%$ eosin and $10 \%$ nigrosin, one drop of $10 \mu \mathrm{l}$ of nigrosin, one drop of $20 \mu \mathrm{l}$ of eosin and one drop of semen of $10 \mu \mathrm{l}$ were used on a tempered slide at $37^{\circ} \mathrm{C}$; allowed to set for 10 to 30 seconds; with a drop of the mixture being made a thick spread in dry sheet; a drop of immersion oil was then placed and the percentage of live and dead sperm per 100-field clear field microscopy was determined. At least 200 cells were evaluated, differentiating those that were partially or totally stained from those that had not allowed the passage of the dye; the result was expressed as the percentage of non-stained spermatozoa which were considered alive (Soler et al., 2005).

To determine the state of the acrosomes, the same fixed sample was used, observing a minimum of 200 spermatozoa. Normal acrosomes were classified as having spermatozoa with well-defined and with well-defined and sharp dark crescent shaped apical edges. Results were expressed as percent of normal acrosomes.

The process should not last more than a minute, since it has been shown that sperms that were alive at death are stained over time; in the dead sperm the permeability of the 
cephalic membrane is altered and the dye is allowed to pass, while the living do not allow it, the dying are stained in the tail.

e) Vitality: in the evaluation of the vitality percentage was counted a number of 100 spermatozoa per sample. In order to perform the sperm spread, we also placed a drop of nigrosine and two drops of eosin on the end of an object holder, and with the help of another tempered object holder, the sample is spread, which must be thin and uniform; let dry for a minute, place a drop of oil immersion and take the microscopic to observe with the lens of 100X. Living sperm were not stained, whereas non-viable or dead sperm became pink.

\section{Post cooling evaluation}

The evaluation of individual post-refrigeration motility was performed, each group studied $(2,4,8,10,24$ hours). The evaluation of the seminal quality was done in fresh and every 24 hours after refrigeration for 5 days; of the sample refrigerated at $5{ }^{\circ} \mathrm{C}$ was taken, 0.5 $\mathrm{ml}$ of semen diluted in an eppendorf tube, which was tempered at $37^{\circ} \mathrm{C}$ for 3 minutes in a water bath; the tube was then removed from the water bath, dried with a paper towel, then $10 \mu \mathrm{l}$ of semen was taken and placed in the container and tempered and placed the coverslip; this evaluation was done on the thermal plate (Chamba Ochoa, 2017).

\section{Statistical analysis}

For the analysis of data, the statistical program IBM SPSS Statistics 2.0 was used. For the description of the data were used averages and the standard deviation of each group studied, in cases where the information obtained corresponded to percentages, these were transformed according to the binomial model of parameters. All data were assessed for normality by the Shapiro-Wilk test. The variables that did not pass in the normality test (non-parametric data) were evaluated by the ANOVA on Ranks test. The variables that passed the normality test (parametric data) were evaluated by the One Way ANOVA test. When the ANOVA indicated a significant effect, the values were compared by applying Tukey's mean comparison test. Finally, the Pearson test was performed to establish the correlation between the measured variables. The level of significance was considered $P$ $<0.05$ (SPSS/PC, 2012).

\section{RESULTS AND DISCUSSION}

\section{Morphometric characteristics of testis and epididymis}

In the study of the morphometric and functional characteristics of the testes/epididymis and recovered spermatozoa, through the use of two methods of sperm retrieval of 
epididyms of bulls slaughtered in the Camal refrigerator of Loja; as part of the descriptive analysis, an average of $33.81 \pm 5.9 \mathrm{~cm}$ was determined for scrotal circumference; 11.94 $\pm 5.8 \mathrm{~cm}$ for testicular length; $6.1 \pm 4.4 \mathrm{~cm}$ for testicular width and $580 \pm 50 \mathrm{~g}$ of testicular weight; $62.76 \pm 4.2 \mathrm{~g}$ for epididymis weight and $17.28 \pm 6.3 \mathrm{~cm}$ epididymis length. Data that relate to those indicated by Saavedra et al., (2012), where it indicates that the weight of each testicle is around 250 to $500 \mathrm{~g}$, the testicular length between 11 and $17 \mathrm{~cm}$ and the width between 5 to $8 \mathrm{~cm}$, likewise (Sudheer 2000), obtained averages of $31.80 \mathrm{~cm}$ for scrotal circumference, $11.36 \mathrm{~cm}$ for testicular length; $5.56 \mathrm{~cm}$ for testicular width or depth; and $267.12 \mathrm{~g}$ for the weight of each of the testicles; $1.96 \mathrm{~cm}$ in length of the epididymis tail and $30.06 \mathrm{~g}$ for the weight of the epididymal tail. Also, (Rodríguez et al., 2000), obtained averages for scrotal circumference of $31.25 \mathrm{~cm}$, weight of epididymal tail $32 \mathrm{~g}$ and $16.63 \mathrm{~cm}$ for the length of the epididymis. The testes were evaluated within the scrotal pockets, measuring scrotal circumference, length, width and testicular weight; as well as length and weight of the epididymis.

\section{Comparative study of the methods of seminal collection of post-mortem epididyms (0 hours)}

Using the retrograde flow technique was collected, (Table 4) on average $2.0 \pm 0.5 \mathrm{ml}$ with a concentration $/ \mathrm{ml}$ of $64.04 \pm 1.3 \times 10^{9}$ spermatozoa/animal, and using the slicing technique of the epididymis (Table 5). An average of $2.2 \pm 0.4 \mathrm{ml}$ was collected with a concentration/ml of $62.12 \pm 2.8 \times 109$ spermatozoa/animal, corresponding to the number of cells obtained in an ejaculation (Gonçalves et al., 2008). Considering that the epididymis is capable of storing several ejaculations, the quantity obtained could be higher however; the bulls used came from a slaughtering plant, where reproductive quality is not a considered index (table 3).

Table 3. Statistical results of the microscopic characteristics according to Protocol.

\begin{tabular}{ccc}
\hline Evaluated parameters & $\begin{array}{c}\text { Semen obtained by } \\
\text { retrograde flushing }\end{array}$ & $\begin{array}{c}\text { Semen obtained by } \\
\text { slicing the } \\
\text { epididymis }\end{array}$ \\
\hline Volume cc. & $2 \pm 0,5$ & $2,2 \pm 0,4$ \\
Mass motility \% & $61,6 \mathrm{~m} \pm 5,3^{\mathrm{a}}$ & $59,2 \pm 4,2^{\mathrm{a}}$ \\
Individual motility \% & $51,8 \pm 3,8^{\mathrm{a}}$ & $49,6 \pm 5,7^{\mathrm{a}}$ \\
Live spermatozoa \% & $62,08 \pm 4,2^{\mathrm{a}}$ & $59,12 \pm 3,5^{\mathrm{b}}$ \\
Sperm concentration $\times 10^{9} / \mathrm{ml}$ & $64,04 \pm 1,3^{\mathrm{a}}$ & $62,12 \pm 2,8^{\mathrm{b}}$ \\
Abnormal spermatozoa \% & $7,92 \pm 1,2^{\mathrm{b}}$ & $9,64 \pm 1,6^{\mathrm{a}}$ \\
\hline ( a b ) Means with a common letter are not significantly different $(\mathrm{p}>0.05)$
\end{tabular}


Table 5. Results of the microscopic evaluation of the semen obtained by retrograde flushingng in different postmortem times (slicing).

\begin{tabular}{cccccc}
\hline $\begin{array}{c}\text { Storage } \\
\text { time }\end{array}$ & $\begin{array}{c}\text { Mass } \\
\text { Motility } \\
\%\end{array}$ & $\begin{array}{c}\text { Individual } \\
\text { Motility \% }\end{array}$ & $\begin{array}{c}\text { Live } \\
\text { spermatozoa } \\
\%\end{array}$ & $\begin{array}{c}\text { Sperm concentration } \\
\mathbf{x 1 0} / \mathbf{m l}\end{array}$ & $\begin{array}{c}\text { Abnormal } \\
\text { spermatozoa \% }\end{array}$ \\
\hline $2 \mathrm{~h}$ & $86 \pm 6,1$ & $76 \pm 5,9$ & $86 \pm 3$ & $69 \pm 2$ & $7,4 \pm 1,3$ \\
$4 \mathrm{~h}$ & $76 \pm 5,7$ & $66 \pm 4,7$ & $76 \pm 4,6$ & $67 \pm 1,8$ & $8,2 \pm 2,4$ \\
$8 \mathrm{~h}$ & $56 \pm 5,5$ & $47 \pm 4,4$ & $63,4 \pm 3,7$ & $56,2 \pm 1,5$ & $8 \pm 2$ \\
$10 \mathrm{~h}$ & $48 \pm 4,2$ & $41 \pm 4$ & $51 \pm 2,2$ & $62,8 \pm 4$ & $6,6 \pm 2,3$ \\
$24 \mathrm{~h}$ & $42 \pm 3,4$ & $29 \pm 3,6$ & $34 \pm 2$ & $65,2 \pm 2$ & $9,4 \pm 2,8$ \\
\hline
\end{tabular}

It was decided to use the average/animal, since according to (Goovaerts et al., 2006) one epididymis can not be control of the other, since there are significant differences in the quantity and quality of the cells collected from the epididymis of the same animal.

The fresh sperm samples presented superior results in all the parameters compared to the results of the evaluation with refrigerated semen.

\section{Semen evaluation obtained by retrograde flushing}

Sperm motility is essential for the sperm to reach the uterine environment and the fertilization site, being considered the most important criterion in the evaluation of sperm cells before and after cryopreservation (Siqueira et al., 2007).

In the present study microscopic characteristics presented similar percentage motile of mass motility within each group, at two post-mortem hours of $86 \pm 6.1 \%$ (Table 5), for the retrograde (P1) method and $84 \pm 4 \%$ (table 6 ), in the method of epididymis slicing (P2), similar to those obtained by Chavez (2008), who obtained $90 \%$ of mass motility in Lidia bulls, considered to be a very good descriptive value. At four hours post-mortem, $76 \pm$ $5.7 \%$ (P1) and $72 \pm 3.8 \%$ (P2) were obtained, with a good descriptive value. At 56 hours post-mortem, $56 \pm 5,5 \%$ (P1) and $54 \pm 3,5 \%$ (P2) were obtained, and at $10 \mathrm{~h}$ and $24 \mathrm{~h}$ a mean mass motility of 40 to $48 \%$ with a regular descriptive value. These descriptive values are in accordance with the reference values presented by Baracaldo (2007), who indicate very good descriptive values of $80-90 \%$, good of $60-79 \%$, regular of $40-59 \%$ and bad less than $40 \%$.

Regarding the individual motility of fresh spermatozoa collected from the epididymis at two hours of storage, it was elevated, $76 \pm 5.9 \%$ (table 5), with retrograde flow technique and $74 \pm 5 \%$ (table 6 ). technique of slicing the epididymis; which can be considered within normal limits for the species, (Melo et al., 2008); values slightly below the $80 \%$ found by Chavez (2008); (P1) and $64 \pm 4.3 \%$ (P2), data similar to those obtained by Sánchez et al. 
(2010), who performed a study to 28 post-mortem Lydia bulls, obtained means of $60 \pm$ $6.1 \%$ of individual motility, with a good descriptive value; in the third group at 8 hours postmortem presented $47 \pm 4.4 \%$ (P1) and $46 \pm 3.9 \%$ (P2) regular; and at $10 \mathrm{~h}$ and $24 \mathrm{~h}$ postmortem values were obtained of 28 and $41 \%$ respectively; giving a poor descriptive value as reported by Barth et al. (2000).

Individual motile readings that were made for both the retrograde flushing protocol and the epididymal slicing protocol did not maintain a uniform pattern; this could be related to the variability between slaughter bulls, non-breeding bulls, and even more so in this study in which we do not know the specific origin of these males destined for consumption and that we understand did not have an adequate diet, which could have affected in some way their reproductive capacity (Albers and Barrios 2006).

\section{Post-refrigeration semen quality at different evaluation times'}

The percentage of individual motility of the spermatozoa obtained by retrograde washing and slicing of the epididymis (slicing), after being refrigerated, the samples were evaluated every $24 \mathrm{~h}$, within each method of collection (Table 6, 7 and 8).

Table 6. Results of the microscopic evaluation of semen obtained by slicing the epididymis (slicing) at different postmortem times

\begin{tabular}{llllll}
\hline $\begin{array}{c}\text { Collection } \\
\text { time }\end{array}$ & $\begin{array}{c}\text { Mass Motilityl } \\
\%\end{array}$ & $\begin{array}{c}\text { Individual } \\
\text { Motility \% }\end{array}$ & $\begin{array}{c}\text { Live } \\
\text { spermatozoa\% } \\
\%\end{array}$ & $\begin{array}{c}\text { Sperm } \\
\text { concentration } \\
\mathbf{x 1 0} / \mathbf{m l}\end{array}$ & $\begin{array}{c}\text { Abnormal } \\
\text { spermatozoa } \\
\%\end{array}$ \\
\hline $2 \mathrm{~h}$ & $84 \pm 4$ & $74 \pm 5$ & $82,6 \pm 2$ & $67 \pm 0,5$ & $9,4 \pm 1,2$ \\
$4 \mathrm{~h}$ & $72 \pm 3,8$ & $64 \pm 4,3$ & $72,2 \pm 1,8$ & $67 \pm 0,3$ & $8 \pm 2$ \\
$8 \mathrm{~h}$ & $54 \pm 3,5$ & $46 \pm 3,9$ & $57,6 \pm 1,5$ & $56,2 \pm 1$ & $10,6 \pm 0,5$ \\
$10 \mathrm{~h}$ & $46 \pm 3,4$ & $36 \pm 4$ & $49,2 \pm 3$ & $58,6 \pm 2$ & $9,8 \pm 1$ \\
$24 \mathrm{~h}$ & $40 \pm 4,6$ & $28 \pm 3,2$ & $34 \pm 3,5$ & $61,8 \pm 3$ & $10,4 \pm 1,5$ \\
\hline
\end{tabular}

Table 7. Percentage of Single Motility evaluated every 24 hours, post cooling semen obtained by retrograde flushing.

\begin{tabular}{|c|c|c|c|c|c|}
\hline \multirow{3}{*}{$\begin{array}{l}\text { Period of seminal } \\
\text { evaluation }\end{array}$} & \multicolumn{5}{|c|}{ Percentage of Individual Motility } \\
\hline & \multicolumn{5}{|c|}{ Post-mortem storage time } \\
\hline & 2 hours & 4 hours & 8 hours & 10 hours & 24 hours \\
\hline $24 \mathrm{~h}$ & $69 \pm 5,8$ & $55 \pm 4,3$ & $37 \pm 3,5$ & $25 \pm 2,7$ & 0 \\
\hline $48 \mathrm{~h}$ & $57 \pm 4,6$ & $45 \pm 4$ & $22 \pm 2,6$ & 0 & 0 \\
\hline $72 \mathrm{~h}$ & $46 \pm 4,5$ & $34 \pm 3,6$ & 0 & 0 & 0 \\
\hline $96 h$ & $37 \pm 3,9$ & $22 \pm 2,4$ & 0 & 0 & 0 \\
\hline $120 \mathrm{~h}$ & $26 \pm 3,5$ & $8 \pm 1$ & 0 & 0 & 0 \\
\hline
\end{tabular}


The percentage of live spermatozoa, determined at $2 \mathrm{~h} 86 \pm 3 \%$ (P1) and $82.66 \pm 2 \%$ (P2); (P1) and $72.2 \pm 1.8 \%$ (P2), data related to those obtained by Chavez M. (2008), who in their study determined 70 and $80 \%$; similar values found by Morillo et al. (2012), who said that the minimum acceptable percentage for live spermatozoa should reach $70 \%$.

Barrios (2002), reported a sperm concentration of 40 to $72 \times 10^{9} \mathrm{spz} / \mathrm{ml}$ in the present study we determined 56.2 to $69 \times 109 \mathrm{espz} / \mathrm{ml}$, higher values than the previous ones and those found by Rodríguez (2000), who reported 15 to 40 x 109 esp/ml. However, Castro et al. (2009) found averages of spermatozoa collected from the tail of the epididymis of $1.7 \times 109 \mathrm{espz} / \mathrm{ml}$, with a minimum of $0.26 \times 109 \mathrm{spz} / \mathrm{ml}$ and a maximum of $4.2 \times 109$ / $\mathrm{ml}$. In other studies, Sánchez et al. (2010) obtained a spermatic concentration of $380.5 \times 109 \mathrm{spz} / \mathrm{ml}$ values lower than those obtained in the present study and that of Chavez (2008), who reported of 600 to $1800 \times 10^{6} \mathrm{spz} / \mathrm{ml}$.

As for morphology, the percentage of abnormal spermatozoa was $7.92 \pm 1.2 \%$, for semen obtained by retrograde flushing and $9.64 \pm 1.6 \%$ for the semen obtained by the epididymis slicing, Barth (2000) and Anel et al. (2002) confirm that the total of abnormalities should not exceed $30 \%$; suggesting that when there are few abnormalities it is sufficient to count 100 spermatozoa and when we find large numbers it is advisable to count 300 or more.

Castro et al., (2009) studied the viability of bull spermatozoa, collected from epididyms refrigerated at $4{ }^{\circ} \mathrm{C}, 24$ hours after slaughter and found results similar to that of semen ejaculated. However, in this study the best results were obtained in groups one and two, within the protocols evaluated; at $24 \mathrm{~h}$, a viability was determined within protocol one (P1) $69 \pm 5.8 \%$ (G1) and $55 \pm 4.3 \%$ (G2); $57 \pm 4.6 \%$ (G1) and $45 \pm 4 \%$ (G2), in protocol 2 (P2) at $48 \mathrm{~h}$; groups 3,4 and 5 did not present individual motility.

Table 8. Percentage of Individual Motility evaluated every 24 hours after cooling of the semen obtained by the epididymis slicing.

\begin{tabular}{cccccc}
\hline \multirow{2}{*}{$\begin{array}{c}\text { Period of seminal } \\
\text { evaluation }\end{array}$} & \multicolumn{5}{c}{ Percentage of Individual Motility } \\
\cline { 2 - 5 } & $\mathbf{2}$ hours & 4 hours & $\mathbf{8}$ hours & 10 hours & 24 hours \\
\cline { 2 - 5 } & $64 \pm 4,7$ & $54 \pm 2,7$ & $37 \pm 3,4$ & $26 \pm 4$ & 0 \\
$24 \mathrm{~h}$ & $52 \pm 4$ & $44 \pm 3,2$ & $18 \pm 2$ & 0 & 0 \\
$48 \mathrm{~h}$ & $41 \pm 3,7$ & $32 \pm 2$ & 0 & 0 & 0 \\
$72 \mathrm{~h}$ & $30 \pm 3,5$ & $16 \pm 1,8$ & 0 & 0 & 0 \\
$96 \mathrm{~h}$ & $20 \pm 2,4$ & 0 & 0 & 0 & 0 \\
$120 \mathrm{~h}$ & &
\end{tabular}


Martins et al. (2009) determined that after 48 hours of refrigeration storage, there is a total decrease in motility, which is in agreement with the results obtained in this work, as confirmed by Anel (2002). , depending on the interval between sperm recovery and death, sperm motility will decrease significantly between 48 hours.

The results showed that there is no significant statistical difference between methods of sperm collection on the spermatozoa viability. Despite this, the viability results were twice the sperm mortality, indicating that the epididymis spermatozoa, after cooling, behave in the same way as the ejaculates (Celeghini et al., 2008), in which immobile sperm can still be viable (Chavez, 2008).

\section{CONCLUSION}

The methods of collection used were efficient and repeatable, confirming that it is possible to collect live spermatozoa from the epididymis tail of postmortem bulls. It can be inferred that these methods do not influence the quantity and quality of epididymal spermatozoa. The samples obtained by the retrograde lavage protocol achieved better results than the epididymal splitting protocol (slicing), although these are not significantly different, and should be emphasized that they are remarkable data, since the literature reviewed does not mention work done by this process; rather they only describe it as a method for obtaining postmortem epididymal spermatozoa. The sperm vitality is directly proportional to the storage time, the best results were in group one, whose collection was carried out at $2 \mathrm{~h}$ post mortem, showed good survival, although they have less mobility than those of bovine semen collected by conventional methods. The best preservation period in refrigeration of epididymal semen collected between 2 and $4 \mathrm{~h}$ post mortem is between 24 and 48h; after this period, individual motility drops significantly; being possible to recover and cryopreservation of epididymis sperm from this material with any protocol selected; which is a promising technique for conserving genetic resources, which has attracted great interest in the case of some animals of high genetic value that have died suddenly.

\section{REFERENCES}

Albers Alvarez MI, Barrios Arismendi DR. 2006. Movilidad individual de los espermatozoides epididimarios de toros post mortem obtenido mediante lavado retrógrado. Zootecnia Tropical. 24 (3), 267-279.

http://www.scielo.org.ve/scielo.php?script=sci_arttext\&pid=S0798-72692006000300006 
Anel L, Gerra C, Alvarez M, Anel E, Martinez A, Boixo C, Kaabi M, Herraez P, Paz P. 2002. Effect of postmortem interval in quality of epididymal spermatozoa in Iberian red deer (Cervus elaphus hispanicus). Theriogenology. 57: 577 (Abstr).

Armas R, Fernández A, Vásquez C. Santiani AA. 2001. Determinación del tiempo máximo para recuperar y criopreservar espermatozoides obtenidos de la cola del epidídimo en caninos post orquiectomía. Revista de Investigaciones Veterinarias del Perú. 3 (22):199207.

DOI:

http://dx.doi.org/10.15381/rivep.v22i3.257

http://revistasinvestigacion.unmsm.edu.pe/index.php/veterinaria/article/view/257

Baracaldo M, Barth A, Bertrand W. 2007. Pasos para el congelamiento de semen bovino: desde la colección del semen hasta el almacenamiento en el tanque de nitrógeno líquido. www.ivis.org/newsletter/archives/apr07/apr3007es.htm

Barbosa Luciano Munita, Kanazawa Mábilis Yumi, Peres Anelise Ribeiro, Ferreira de Souza Fabiana. 2012. Viabilidade do sêmen congelado obtido do epidídimo de touros post-mortem. Revista Brasileira de Ciencias Veterinarias. 3 (19):190-194. DOI: http://dx.doi.org/10.22409/rbcv.v19i3.69 http://www.rbcv.uff.br/rbcv/article/view/69

Barrios AD. 2002. Evaluación de la calidad y capacidad fecundante de espermatozoides de la cola del epidídimo de toros Post Mortem. (U. C. Venezuela, Ed.) IX Congreso venezolano de Producción e Industria Animal. Valera, Venezuela.

Barth A, Bo G, Tríbulo H. 2000. Curso de evaluación de toros y control de la calidad seminal. (U. c. Córdoba, Ed.).

Castro JB, Casas VF, Souza FF. 2009. Viabilidade dos espermatozóides colhidos do epidídimo de touros 24 horas post-mortem. Resúmenes del Congresso Brasileiro de Reprodução Animal, Belo Horizonte, Brasil. 379 p.

Celeghini E, Arruda R, Andrade A, Nascimento J, Raphaela C, Rodrigues P. 2008. Effects that bovine sperm cryopreservation using two different extenders has on sperm membranes and chromatin. Anim Reproduction Science. 104:119-131. https://doi.org/10.1016/j.anireprosci.2007.02.001

Chávez M. 2008. Comparación en pruebas microscópicas pre-congelación y post descongelación de semen de toros de lidia post mortem. Recuperado el 16 de febrero de 2015, de http://androvet.blogspot.com/ 
Gonçalves PBD, Figueiredo JR, Freitas VJ. 2008. Biotécnicas aplicadas à reprodução animal (Segunda ed.). São Paulo, Brasil: Editora Roca. 408-410 p.

Goovaerts IGF, Hoflack GG. Van Soom A, Dewulf J, Nichi M, Kruif de A, Bols PEJ. 2006. Evaluation of epididymal semen quality using the Hamilton-Thorne analyser indicates variation between the two caudae epididymides of the same bull. Theriogenology. 66 (2):323-330. DOI: http://dx.doi.org/10.1016/j.theriogenology.2005.11.018 http://www.theriojournal.com/article/S0093-691X(05)00522-4/abstract

James AN, Green H, Hoffman S, Landry AM, Paccamonti D, Godke RA. 2002. Preservation of equine sperm stores in the epididymis at $4^{\circ} \mathrm{C}$ for $24,28,72$ and 96 hours. Theriogenology. 58:401-404. https://doi.org/10.1016/S0093-691X(02)00883-X

Martins CF, Rumpf R, Pereira DC, Dode MN. 2007. Cryopreservation of epididymal bovine spermatozoa from dead animals and its uses in vitro embryo production. Animal Reproduction Science. 101:326-331. https://doi.org/10.1016/j.anireprosci.2007.01.018

Martins CF, Driessen K, Melo Costa P, Carvalho-Neto JO, De Sousa R, Rumpf R, Dodec MN. 2009. Recovery, cryopreservation and fertilization potential of bovine spermatozoa obtained from epididymides stored at $5{ }^{\circ} \mathrm{C}$ by different periods of time. Animal Reproduction Sciense. 116:50-57. https://doi.org/10.1016/j.anireprosci.2008.12.018, https://www.researchgate.net/profile/Jose_Carvalho33/publication/23963381_Recovery_ cryopreservation_and_fertilization_potential_of_bovine_spermatozoa_obtained_from_ep ididymides_stored_at_5C_by_different_periods_of_time/links/54f87b450cf210398e96a9 51/Recovery-cryopreservation-and-fertilization-potential-of-bovine-spermatozoaobtained-from-epididymides-stored-at-5C-by-different-periods-of-time.pdf

Melo, C. M., Papa, F. O., Fioratti, E. G., Villaverde, A. I., Avanzi, B. R., \& Monteiro, G. 2008. Comparison of three different extenders for freezing epididymal stallion sperm. Animal Reproduction Science. 3(107):331. https://doi.org/10.1016/j.anireprosci.2008.05.108

Morillo M, Salazar S, Castillo E. 2012. Evaluación del potencial reproductivo del macho bovino. Instituto Nacional de Investigaciones Agrícolas. 60 p.

Oyeyemi MO, Ubiogoro O. 2005. Espermiograma y Características Morfológicas de los Espermatozoides en el Testículo y Epidídimo del Verraco Grande Blanco en Nigeria. International Journal of Morphology. 23(3):237-238. http://dx.doi.org/10.4067/S0717- 
Reyes-Moreno, C., Boilard, M., \& Sullivan, R., Sirard M. 2002. Characterization and identification of epididymal factors that protect ejaculated bovine sperm during in vitro storage. Biol. Reprod. 66(1):159-166. https://doi.org/10.1095/biolreprod66.1.159

Rodríguez Márquez J, Madrid Bury N, Aixa U, Atilio Aranguren J, Quintero A. 2000. Análisis morfométrico del epidídimo en toros jóvenes mestizos $5 / 8$ Holstein y $5 / 8$ Pardo Suizo con testículos pequeños. (U. d. cientifica, Ed.) Revista científica, FCV-LUZ. 10(6):458-467.

http://www.fcv.luz.edu.ve/images/stories/revista_cientifica/2000/06/articulo4.pdf

Sánchez Israel V, Aguiar Loria A, Erosa Denis S, Cervera P, Avilés Ávila V, Navarrete Sierra L, Magaña Sevilla Hector, Baeza Rodríguez Juan, Ortiz de la Rosa Benjamín, Ramón Ugalde Julio. 2010. Congelacion postmortem de semen de toro lidiado. Subdirección de Coordinación de Enlace Operativo de la DGETA en Mérida, Yucatán. http://www.centrotorolidia.es/opencms_wf/opencms/system/modules/es.jcyl.ita.site.torod elidia/elements/galleries/galeria_downloads/

Saavedra GD, Mas A, Sanes Vargas JM, Vallejo P, Matás Parra C, Seva JI. 2012. Parámetros testiculares y características morfológicas de los espermatozoides epididimarios obtenidos postmorten en el toro de lidia. Anales de Veterinaria de Murcia. 28: 7-13. http://revistas.um.es/analesvet/article/view/188671/155411, https://doi.org/10.6018/j/188671

Siqueira JB, Guimarães JD, Costa EP, Henry M, Torres CA, Silva M. 2007. Relação da taxa de gestação com sêmen bovino congelado e testes de avaliação espermática in vivo. Revista Brasilera de Zootecnia. 36:387-393. https://doi.org/10.1590/S151635982007000200016

Soler AJ, Esteso MS, Fernández SMR, Garde JJ. 2005. Characteristics of Iberian red deer (Cervus elaphus hispanicus) spermatozoa cryopreserved after storage at $5^{\circ} \mathrm{C}$ in the epididymis for several days. Theriogenology. 64(7):1503-1513. http://www.sciencedirect.com/science/article/pii/S0093691X05001056 
Sostaric E, Alberts MBM, Gadella BM, Stout TAE. 2008. The roles of the epididymis and prostasomes in the attainment of fertilizing capacity by stallion sperm. Animal Reproduction Science. 107:237-247. https://doi.org/10.1016/j.anireprosci.2008.04.011

Sudheer S. 2000. Relationship between testicular size and seminal attributes in crossbred bulls. Indian journal of animal research. 34(2):159-160. http://arccjournals.com/journal/indian-journal-of-animal-research/ARCC3548

Tittarelli C, Savignone CA, Arnaudín E, Stornelli MC, Stornelli MA, De la Sota RL. 2006. Effect of storage media and storage time on survival of spermatozoa recovered from canine and feline epididymides. Theriogenology. 66(6):1637-1640. https://doi.org/10.1016/j.theriogenology.2006.01.021

Yu I, Leibo SP. 2002. Recovery of motile, membrane-intact spermatozoa from canine epididymides stored for 8 days at 4 degrees C. Theriogenology. 3(57):1179-1189. https://doi.org/10.1016/S0093-691X(01)00711-7 